\title{
Supporting Production System Development through the Obeya Concept
}

\author{
Siavash Javadi, Sasha Shahbazi, and Mats Jackson \\ Mälardalen University, School of Innovation, Design and Engineering, Eskilstuna, Sweden \\ \{sji10001, ssi10002\} @student.mah.se, \\ mats.jackson@mah.se
}

\begin{abstract}
Manufacturing Industry as an important part of European and Swedish economy faces new challenges with the daily growing global competition. An enabler of overcoming these challenges is a rapid transforming to a value-based focus. Investment in innovation tools for production system development is a crucial part of that focus which helps the companies to rapidly adapt their production systems to new changes. Those changes can be categorized to incremental and radical ones. In this research we studied the Obeya concept as a supporting tool for production system development with both of those approaches. It came from Toyota production system and is a big meeting space which facilitates communication and data visualization for a project team. Four lean companies have been studied to find the role of such spaces in production development. Results indicate a great opportunity for improving those spaces and their application to radical changes in production development projects.
\end{abstract}

Keywords: Production system development, Obeya, Kaikaku, Kaizen, Data visualization.

\section{Introduction}

The manufacturing industry is one of the dominant sectors of the European economy providing jobs for around 34 million people, and producing an added value exceeding $€ 1500$ billion from 230000 enterprises with 20 and more employees. Also, a large part of the growing service sector in Europe is linked to the manufacturing companies. However, the manufacturing industry in Europe faces intense and growing competitive pressure on several fronts.

Although innovative and effective organization of operations has been the basis for industrial success and competition since the days of Ford, current challenges put new and stronger pressure on European manufacturing industry than ever before. Globalization, demographic changes, environmental challenges and new values drives increased demands on resource efficiency, sustainable manufacturing, and innovative and individualized products.

Manufacturing in mature traditional sectors is increasingly migrating to low-wage countries such as China, India, Mexico and Brazil, but these countries are not 
standing still in their development. On the contrary, they are rapidly modernizing their production methods and enhancing their technological capabilities - in many cases building new green field sites, which means that they do not only have low labor cost but also the latest technology. In meeting such extensive competition, Swedish manufacturing industry both needs to build on existing strengths and find new ways to compete. One solution is to build on the under-utilized potential of innovative production development instead of mainly emphasizing on the operations phase, i.e. running production. Our industrial historical base and infrastructure give particularly good preconditions for Swedish manufacturing companies to compete with innovative production development as a very effective strategy.

Also, to succeed in developing new efficient products and processes and thereby withstand and handle the global competition, continuous development and improvements as well as radical changes around existing production processes and technology are required. Thus, innovation in relation to production is becoming a crucial area which includes e.g. new business models, new modes of 'production engineering', efficient industrialization of new products and an ability to profit from ground-breaking manufacturing sciences and technologies. Innovation in both new production technology and new ways of working during development and operations is often difficult for competitors to get hold of and copy. Hence, it falls into the competitive advantage category of differentiation as a way to take offensive action in creating a defendable position in industry and generating a superior return on investment, according to Porter (1990)definition.

In summary, the challenges facing the manufacturing sector in Sweden require radical transformations from a cost-based to a value-based focus. An ability to constantly adapt and improve the production operations and working procedures will bring about the required changes. To tackle them appropriately, manufacturing companies need to invest in creativity, entrepreneurship and new innovation models, specifically in the area production system development. Thus, an overall objective and research question is how to support innovation in production system development. One of the tools introduced by lean philosophy is Obeya or war room for development projects which will be explained in details in section 2.2 of this paper. In this research we are trying to illustrate how Obeya or similar meeting places can support innovative production system development.

\section{Theoretical Framework}

\subsection{Production System Development}

Different research traditions have contributed to the current state of knowledge concerning production system development. From an operations strategy perspective, Hayes and Wheelwright (1979) introduced the product-process matrix in order to choose production system layout according to product and process life cycle stage. Miltenburg (2005) defines seven production systems and put them in a matrix in order to analyze similarities and differences between them. However, according to Cochran et al. (2002), Miltenburg (2005) and Hayes and Wheelwright (1979) fail to 
communicate how lower level design decisions, such as equipment design, operator work content and so on, will affect system performance. These approaches treat production system design as a problem of selecting an appropriate off-the-shelf design from a given set of choices and criteria. Designers are not given the freedom to create a unique production system to satisfy a broad set of requirements in a particular environment.

Examples of research from an industrial engineering perspective in the production system design area are the technology focused book by Bennett (1986), methods based on Integrated Definition for Function Modeling 0 (IDEF0) by for example Wu (2001) and methods based on the function/solution mapping in Axiomatic Design, such as Suh (1990), Kulak et al. (2005), Cochran et al. (2002), and Almström (2005). The system approach is taken on the production system problem by Seliger et al. (1987). Examples of other approaches for systematic design and evaluation of production systems are: Bellgran (1998), Säfsten (2002), Bellgran and Säfsten (2005), Wiktorsson (2000) while methods based on the stage gate method e.g. Ulrich and Eppinger (2003) are developed further by e.g. Blanchard and Fabrycky (1998) and Wu (1994).

Innovation in a production system development perspective is given by Manufuture which describes the need of innovating production by "...important research, innovation and education activities that could transform the competitive basis of producing and delivering products and services that reach a new level in satisfying society's desires and expectations" (Manufuture, 2006).

Innovation in production can also be related to improvements and changes within the production system, innovative production capabilities. In general, two approaches towards production system improvements are commonly recognized: (1) incremental / continuous improvements and (2) infrequent and radical improvements. The first type (called Kaizen in Japanese) is a well-known approach for improving production. Kaizen became widely known after the introduction by Imai (1986) and is widely used within the lean production paradigm. The key characteristics of Kaizen are often described as continuous, incremental improvement in nature, participative, and process-oriented. The concept has been extensively described, and a number of supporting methods and tools have been developed and widely applied in industry.

The radical improvement approach or "Kaikaku" in Japanese has also been conducted by many companies. However, it has been less documented and conceptualized compared to continuous improvement. Radical changes are conducted infrequently, involving some fundamental changes within production and causing dramatic performance gain, and they are often initiated by top or senior management (Yamamoto, 2010).

\subsection{Obeya}

In this paper we studied Obeya as an innovation support tool for production system development with both above mentioned approaches. The Obeya concept is a part of Toyota product development system which has been used as a project management tool in Toyota. The concept was introduced during the development process of Prius 
in late 90's and since then it has become a standard tool for product development projects in Toyota (Morgan and Liker, 2006) . Obeya in Japanese simply means "big room". However, it has also been called with other names such as "war room", "program room", "control room" and "the pulse room" in different researches and companies. By any name, Obeya is an advanced visual control innovation room where activities and deliverables are outlined and depicted in a visual format to be discussed in frequent meetings. A cross functional team including design and production engineers and other decision makers gathers in a single big room to make real time key decisions on the spot. Andersson and Bellgran (2009) assert that Obeya saves the time since it is not required to move to conference room or others rooms since people are already present in a single room to provide information and answer the questions. In Obeya it is not just the chief engineer who manages the process but all involved people contribute in the decision making process (Liker, 2004), which leads to higher level of cross-functionality in the process (Söderberg and Alfredson, 2009).

Effective data visualization is another benefit of Obeya (Söderberg and Alfredson, 2009). The big room's walls are covered by different types of data to help the project team to make more informed decisions through simple and instant access to all required information in one place simultaneously. Visualized data can be designs and drawings, schedules and plans, technical specifications etc. "Engineers plaster the room's walls and mobile walls with information organized by vehicle part... and this information allows anyone walking the walls to assess program status (quality, timing, function, weight) up to the day" (Morgan and Liker, 2006).

Andersson and Bellgran (2009)describe the benefits of Obeya as following:

- Helping to make plan, do, check and action cycle shorter through gathering all decision makers in a single place

- Facilitating communication between team members through face to face daily contact

- Supporting the product development through combination of effective communication and proper technology

- Providing an infrastructure for idea generation and development for both new products and cost reduction.

Since very few studies have been done about obeya and its application to production development, we studied the current practice of using Obeya or similar meeting places in lean companies directly. We have studied four companies in Sweden who have been working according to the lean principles for several years. The goals of study were to understand

- The uses of meeting places and its contribution to production system development

- The methodology and work process related to those uses

- Data visualization methods and tools used. 


\section{$3 \quad$ Research Method}

To gather required information, semi-structured interview and direct observation techniques were used for the case studies. That type of interview was chosen for this research due to flexibility, allowing discussing and causing to come up with new questions during the interview. At each company along with interviews, production processes observed directly, meeting places were visited and in one of the cases authors participated in the daily morning meeting of the company for daily production issues. All meetings, interviews and visits were documented through voice recording and its transcription as well as taken notes.

All studied companies are a part of international companies or groups which are considered as one of the leading names in their industries. Cases are named company $\mathrm{A}, \mathrm{B}, \mathrm{C}$ and $\mathrm{D}$ and they belong respectively to material handling equipment, automotive, construction and automotive parts industries.

Company A has about 1800 employees in 5 assembly lines and 2 production departments. Company b is large size company with almost 1200 employees working in 3 different main departments. Company $\mathrm{C}$ is medium size company with almost 100 employees with a single production line. Case D is also a medium size company with almost 150 employees with 5 different product assembly lines.

A cross-case analysis was done in order to compare the gathered information and data from the cases and their uses of meeting places for production system development.

\section{$4 \quad$ Results}

Gathered data from interviews and visits shows the following results:

A Single meeting place is used in company A to manage daily production problems and Kaizen projects in the whole factory. Every department and line has their own 5 to 10-minute morning meeting in the meeting place. Meetings are held to discuss last day problems of the related line with people related to the problem. Predefined A4 forms are used for registering the problem. Responsible person has 24 hours for finding the root cause and suggesting a temporary or permanent solution for it. Data registration and visualization process are totally manual. Forms and reports are kept on the room walls as a visualization tool for follow ups. A similar space with similar design and tools is also used for problems related to suppliers.

In company $\mathrm{B}$, each department and line has its own meeting places. There is a general design for meeting places in production and assembly departments which includes daily data about quality, production and safety issues. Maintenance department has it is own special room design. There are number of customized visualization tools including different schedules and reports for ongoing maintenance kaizen projects. Generally same process as company A is followed in company B. short meetings about 10 minutes are held every morning with main actors. But no deadline exists for finding the root cause and solution. 
Company $\mathrm{C}$ has single meeting place which is used for 30-minute morning meetings about production problems, solutions and kaizen projects. Despite other 3 cases, company C's meeting space is in the form of separate room from the production line because of noise disturbance in production line. In addition to conventional visualization tools like white boards, forms and reports, improvements tags are also used to mark source of the problem in the production line. Also digital tools are used for visualizing some information about current situation of production.

Company D has one meeting place for each of its five active production lines. 10minute morning meetings are held with contribution of line operators and supervisor to mainly follow the production rate and its fluctuations. But some kaizen projects are also followed on those meetings. Few basic visualization tools including white boards and A4 forms for Kaizen projects are used.

In all of the cases Kaizen projects refers to minor production system development mostly initiated by problems in production process, defects in products, deviations from production schedules or safety incidents. Also A3 reports in all cases are more or less similar and come from Toyota data visualization system. They are single piece of A3 paper which simply show and document the whole process of identifying a problem in production system and developing a solution for it (Liker, 2004).

Table 1 shows the summary of the results from gathered data through the interviews and visits.

Table 1. Summary of gathered data about production development meeting spaces

\begin{tabular}{|c|c|c|c|c|}
\hline Company & $\begin{array}{c}\text { Meeting place } \\
\text { type }\end{array}$ & Purpose & Visualization tools & $\begin{array}{l}\text { Meeting time } \\
\text { (Minutes) }\end{array}$ \\
\hline A & $\begin{array}{l}\text { Single place for } \\
\text { all lines }\end{array}$ & Kaizen projects & $\begin{array}{c}\text { Predefined A4 } \\
\text { forms, A3 reports, } \\
\text { boards }\end{array}$ & $5-10$ \\
\hline B & $\begin{array}{c}\text { Multiple } \\
\text { customized } \\
\text { places for each } \\
\text { department }\end{array}$ & $\begin{array}{c}\text { Kaizen projects, } \\
\text { General } \\
\text { development } \\
\text { projects }\end{array}$ & $\begin{array}{l}\text { Predefined A4 } \\
\text { reports in the lines, } \\
\text { customized reports, } \\
\text { schedules and charts } \\
\text { for maintenance } \\
\text { department, boards }\end{array}$ & Up to 10 \\
\hline $\mathrm{C}$ & $\begin{array}{l}\text { Single room for } \\
\text { single } \\
\text { production line }\end{array}$ & Kaizen projects & $\begin{array}{l}\text { Predefined A4 } \\
\text { reports, problem } \\
\text { reporting tags, } \\
\text { digital screen for } \\
\text { production status, } \\
\text { boards }\end{array}$ & Up to 30 \\
\hline $\mathrm{D}$ & $\begin{array}{l}\text { Multiple places } \\
\text { for each } \\
\text { assembly line }\end{array}$ & $\begin{array}{c}\text { Production, } \\
\text { quality and safety } \\
\text { control }\end{array}$ & $\begin{array}{c}\text { Simple quality and } \\
\text { production A4 } \\
\text { reports, boards }\end{array}$ & Up to 10 \\
\hline
\end{tabular}




\section{$5 \quad$ Discussion and Conclusion}

As the results indicate, in all cases the meeting spaces are used only for performing incremental changes which are basically minor modifications in production systems. These modifications are mostly initiated by occurrence minor problems in production process, defected products or safety issues and solutions are developed using lean tools like 5whys and $5 \mathrm{Ws}$ which are main tools for preparing A3 reports. Currently there is no indication of using such meeting spaces in radical changes in production system development such as developing and implementing new production system or general modification in current production systems in those companies. In such cases production system development is mostly considered as a part of product development process according to its dependence to developing new products (Bruch, 2012). But in practice it is a huge complex separate project. Obeya meeting spaces can be used for acquiring and generating production system development information like idea development sessions and designing production system. It can also be a very useful tool for sharing and using information especially during the implementation of radical changes in production systems.

In addition, current meeting spaces are not adequately capable of transferring data and results to involved internal actors like people in other production sites as well as external ones like suppliers. This could be mainly because of total dependence of those spaces to non-digital tools.

As Bruch (2012) explains, design information management as a critical part of production system design and development consist of three main parts: acquiring, sharing and using design information. Obeya or such meeting spaces can be used for these purposes in production system design and development process. Using digital tools can help the two latter parts through facilitating sharing and using acquired data in a faster and more effective manner.

In summary, review of the Obeya concept, its advantages and its current practice in industry shows that it can be applied to other purposes than product development projects. The case studies show that similar meeting places are already used for incremental production system development projects. Radical improvements can even benefit more from this concept because of their nature that needs to implement great changes in a short time which usually demands considerable amount of close teamwork. But to maximize the benefits methods and visualization tools used in a conventional Obeya should be customized to be adapted to this purpose.

\section{References}

1. Almström, P.: Development of Manufacturing Systems - A Methodology Based on Systems Engineering and Design Theory. Chalmers University of Technology, Göteborg (2005)

2. Andersson, J., Bellgran, M.: Spatial design and communication for Improved Production Performance. In: Proceedings of the International 3rd Swedish Production Symposium, Göteborg, Sweden (2009)

3. Bellgran, M.: Systematic design of assembly systems: preconditions and design process planning. PhD Thesis, Linköping University (1998) 
4. Bellgran, M., SäFsten, K.: Produktionsutveckling, Utveckling och drift av produktionssystem, Studentlitteratur, Lund (2005) ISBN 91-44-03360-5

5. Bennett, D.: Production Systems Design. Butterworth-Heinemann, London (1986)

6. Blanchard, B.S., Fabrycky, W.J.: Systems Engineering and Analysis (1998)

7. Bruch, J.: Management of Design Information in the Production System Design Process. $\mathrm{PhD} \mathrm{PhD}$ thesis, Mälardalen University, School of Innovation, Design and Engineering (2012)

8. Cochran, D.S., Arinez, J.F., Duda, J.W., Linck, J.: A decomposition approach for manufacturing system design. Journal of manufacturing systems 20, 371-389 (2002)

9. Hayes, R.H., Wheelwright, S.C.: Link manufacturing process and product life cycles. Harvard Business Review 57, 133-140 (1979)

10. Imai, M.: Kaizen (Ky'zen), the key to Japan's competitive success. McGraw-Hill (1986)

11. Kulak, O., Durmusoglu, M.B., Tufekci, S.: A complete cellular manufacturing system design methodology based on axiomatic design principles. Computers \&amp; Industrial Engineering 48, 765-787 (2005)

12. Liker, J.K.: The Toyota Way: 14 Management Principles from the World's Greatest Manufacturer. McGraw-Hill (2004)

13. Manufuture. Assuring the future of manufacturing in Europe (2006), http: / /www. manufuture.org/

14. Miltenburg, J.: Manufacturing Strategy: How To Formulate and Implement A Winning Plan. Productivity Press (2005)

15. Morgan, J.M., Liker, J.K.: The Toyota Product Development System: Integrating People, Process, and Technology. Productivity Press (2006)

16. Porter, M.E.: The competitive advantage of nations: with a new introduction. Free Press (1990)

17. Seliger, G., Viehweger, B., Wieneke-Toutouai, B., Kommana, S.R.: Knowledge-based Simulation of Flexible Manufacturing Systems. In: The Second European Simulation Multiconference, Vienna, Austria, pp. 65-68 (1987)

18. Suh, N.P.: The Principles of Design. Oxford University Press, USA (1990)

19. Säfsten, K.: Evaluation of Assembly Systems: An Exploratory Study of Evaluation Situations, Linköping, Sweden, Division of Production Systems, Department of Mechanical Engineering (2002)

20. Söderberg, B., Alfredson, L.: Building on Knowledge, An analysis of knowledge transfer in product development. Chalmers University of Technology (2009)

21. Ulrich, K., Eppinger, S.: Product Design and Development. McGraw-Hill, Irwin (2003)

22. Wiktorsson, M.: Performance assessment of assembly systems. KTH, Institutionen för produktionssystem (2000)

23. Wu, B.: Manufacturing Systems Design and Analysis: Context and techniques. Chapman \& Hall, London (1994)

24. $\mathrm{Wu}, \mathrm{B}$.: A unified framework of manufacturing systems design. Industrial Management \& Data Systems 101, 446-469 (2001)

25. Yamamoto, Y.: Kaikaku in production. PhD, Mälardalen Universuty (2010) 